\title{
Public Accountability in Collaborative Governance: Lessons from Korean Community Centers*
}

\begin{abstract}
Jaeho Eun**
Abstract: Even the best governance and public administration systems can fail because of lack of accountability. This paper reviews the factors likely to affect the accountability of the collaborative governance system and suggests concrete measures to ensure accountability. As an empirical case of collaborative governance, 300 Korean community centers were sampled by region and by size. Exploratory Factor Analysis was conducted to identify the determinant factors for the accountability of collaborative governance. This analysis found the following factors to be the most important in ensuring accountability in a collaborative governance system: clarity of laws and regulations, representativeness of participants, transparency and democracy in the decision-making process, and performance management and incentive systems. The analysis also found that it is necessary to conceive different performance management and incentive systems for public and civil groups.
\end{abstract}

Keywords: collaborative governance, accountability, Korean community centers

\section{EMERGENCE OF COLLABORATIVE GOVERNANCE AND ACCOUNTABILITY}

The decision-making process of the Korean government has moved, over the past two decades, toward more inclusive and participatory processes involving multiple stakeholders. In the past, during the authoritarian political regime, most decisions were made by a few government departments and a small number of policy makers. Recently, however, issue-oriented decision-making networks have been emerging,

* This paper was presented at the Public Administration and Governance in a Time of Global Economic Turbulence conference, organized by the Korea Institute of Public Administration (KIPA), in Seoul, Korea, October 9, 2009. The author is grateful for the comments of Jon Pierre, Changzheng Dai and his colleagues at KIPA.

** Jaeho Eun is a principal researcher at the Korea Institute of Public Administration. E-mail : eun@kipa.re.kr

Manuscript received January 27, 2010; out for review March 7, 2010; review completed April 18, 2010; accepted April 20, 2010.

The Korean Journal of Policy Studies, Vol. 25, No. 1, 143-173 (2010)

(C) 2010 by the GSPA, Seoul National University 
conforming to the New Public Management governance paradigm, which emphasizes participation and collaboration as core values and proposes a variety of management skills to promote efficiency, effectiveness, and democracy in public administration (Rhodes 1997; Pierre and Peters 2000; Jessop 2001).

However, a governance system, which is often suggested as a cure-all for contemporary public administration, is subject to failure-similar to market failure in the nineteenth century and government failure in the twentieth century (Dunsire 1996; Jessop 1998, 2002; Kooiman 2003). Many studies have demonstrated a possibility of governance failure and have provided diverse diagnoses, which can be categorized into two types (Eun et al. 2009, 2-3).

The first is a failure to properly cope with conflicts that arise with expansion of policy-decision units. Governance is an attempt to improve policy efficiency and effectiveness by ensuring participation of various stakeholders in the process of policy making. However, with expanding policy-decision units, unexpected tension can break out, and without proper management, serious social disruption or unnecessary social costs may be incurred (Pierre and Peters 2000; Bae 2005; Suh and Min 2005, 27). As can be seen in large-scale national projects with far-reaching impacts, such as constructing a nuclear waste disposal site or a large tunnel, reclamation of tideland, or transfer of a military base, policy making and implementation often confront seemingly insurmountable difficulties because a collaborative relationship fails to form among interested parties.

The second type of failure is that of weakened accountability caused by participation and power distribution among a variety of stakeholders. Under state-centered governance, the attribution of responsibility was clear. But under private-public collaborative governance, the question of who has how much responsibility and for whom or what has become ambiguous as the scope of policy making expands (Schubeler 1996; Tendler 1997; Taylor 2007). Civil servants tend to make up for the loss of their power by shedding as much responsibility as possible, and new policy-making participants evade responsibility while claiming rights, aggravating the problem of accountability. Lack of accountability subsequently leads to delay in the work process, poor communication, and poor quality, and may further widen the chasms between participants.

In that context, this study examines factors likely to affect accountability of collaborative governance and to develop an accountability index for an assessment framework. To this end, it examines community centers in Korea as an empirical example of collaborative governance. The community center approach was adopted in Korea in 1999, and as of March 2008, 2,621 centers were operating on the principle of publicprivate collaboration, which engages public agencies, local residents, and nongovernmental and nonprofit organizations to form networks to address local issues. It 
accounts for 73.9 percent of a total of 3,547 local offices in the country.

This study reviews different definitions of accountability and accountability indexes provided in the literature and explores their relevance to collaborative governance. The premise of the study is that existing accountability indexes based on studies of bureaucratic systems do not adequately reflect the structure and characteristics of collaborative governance, and that it is necessary to develop a new index to measure the accountability of collaborative governance. To this end, the study surveyed $300 \mathrm{com}-$ munity centers across Korea and analyzed the responses based on the centers' location and size.

This paper reviews existing theory on the subject, constructs an operational index that can assess the accountability of community centers in Korea, and introduces a research methodology. It then presents the survey results and analyzes them, using exploratory factor analysis (EFA) for 23 measurement items to determine how they can be grouped. Factors to consider in designing an accountability index for collaborative governance are presented, followed by suggestions on how accountability of collaborative governance can be ensured by using the identified index.

\section{THEORETICAL BACKGROUND}

Researchers have provided widely varying definitions of accountability without reaching a consensus on its scope or format. Its definition becomes ever more confusing as more research is conducted. An equally strenuous effort is being made to simplify the concept of accountability (Jos and Tompkins 2004; Bovens 2007; Erkkila 2007). This suggests that content and type of accountability may vary according to context (Peters 1989, 252-53; Sinclair 1995; Romzek and Dubnick 2000, 34-35) and indicates that accountability is not a fixed or universally applicable concept. Similarly, methods to improve accountability may vary according to circumstances (Day and Klein 1987; Erkkila 2007, 7).

\section{Concept of Accountability}

Accountability originates from the word accounting, and the concept has been in use since the ancient Greek era (Lee and Yang 2007, 80-81). Initially, the idea was to conduct bookkeeping or auditing to provide information to people outside an enterprise. The concept evolved over time, and today, simply put, accountability of public administration is connected to answerability. Definitions of accountability include the following: 
- Edwards and Hulme (1996) argued that accountability indicates that individuals and organizations should report all activities for which they are responsible to a higher authority.

- Choung (1996) and Romzeck and Dubnick (2000) defined accountability as an act of explaining, reporting, and elucidating actions and conforming to external judgment.

- Kim, No, and Lee (2004) said that accountability indicates that one party explains and responds to other interested parties about its discretion regarding rights and obligations, accommodates criticism and requirements, takes actions accordingly, and bears responsibility for failure, inability, and neglect.

It is common to understand accountability in relation to answerability, but different researchers emphasize different points, and their studies contain a wide variety of fine points.

- Harmon (1981) argued that accountability can be made official through law, regulation, court order, or other authoritative mandate, and that accountability occurs when control over a civil servant's action comes from outside a particular organization or from other individuals. He emphasized answerability and control in the concept of accountability, as well as the official nature of accountability.

- Sharkansky (1982) argued that accountability is an administrative form of obedience to orders and instructions from higher authority as specified in a proper format. He connected the concept of answerability with subordination.

- Shah (2006) defined accountability as observance of regulations, stressing the legal and systematic character of the concept.

- Mosher (1982) argued that accountability is justification of individuals' acts based on objective obligations based on laws and regulations.

- Choe (2003) said that accountability indicates who is responsible to provide feedback to a particular action or character in a public organization, putting emphasis on the subject (holder) of accountability.

- Lee and Yang (2007) defined accountability as an obligation to provide responsible explanation and to explain how resources are efficiently and effectively used and with what significant outcomes and social contributions. They emphasized the aspect of performance in accountability.

Kim, Lee, and Lee $(2005,544)$ provided a definition of accountability on two levels. In a narrow sense, accountability is a legal obligation to carry out stipulated tasks. Then, there is a wider definition of accountability that goes beyond the matter of answerability. Although these researchers did not provide further explanation, the most common component is responsibility. 
Accountability and responsibility are occasionally used interchangeably, but strictly speaking, they are different concepts. As researchers provide different definitions for the two concepts, it is hard to accurately define their relationship. Some scholars argue that accountability and responsibility are separate concepts; others argue that they are synonymous; still others see responsibility as a part of accountability, or accountability as a part of responsibility. The most widely accepted definitions are summarized below:

- Accountability and responsibility as separate concepts: Kernaghan (1978) distinguished between objective responsibility (accountability) and subjective responsibility (responsibility). Choung $(1996,268)$ argued that responsibility involves wide-ranging moral values and self-regulated obligations and is different from accountability, which involves legal and forced obligations. Shah (2006) regarded accountability as observance of legal and systematic regulations and responsibility as the principle of earning people's trust by improving the quantity, quality, and efficiency of public service.

- Accountability and responsibility as the same: Cooper (1982) argued that both objective and subjective responsibility fall under the category of responsibility. Kim, No, and Lee (2004) defined responsibility as the act of providing explanation and response to interested parties about their discretion on right and obligation, conforming to critique and requirements and taking actions accordingly and bearing responsibility for failure, inability, and neglect.

- Responsibility as part of accountability: Mulgan (2001) argued that responsibility contains many internal, personal, moral, and ethical values, while accountability has a far larger scope, as it includes official systematic responsibility. Moreover, accountability interacts with responsiveness, unlike responsibility, and thus is a far more complex concept.

- Accountability as part of responsibility: Bark (2001) defined responsibility as combining accountability and responsiveness. Similarly, Lee K. (2005) regarded accountability as an objective obligation and responsibility as a subjective obligation that is further reaching than the objective obligation.

\section{Accountability Index}

Definitions of accountability thus range from simple answerability to more complex concepts that include aspects of control, performance, responsibility, and responsiveness. Accountability is not merely about obligation in accounting for a report, but involves a process of explaining and reporting on overall business activities and management (Choung 1996, 272). Here, report and explanation include grounds and justification for one's tasks of the past, present, and future and acknowledgement of penal- 
ties for mistakes instead of mere provision of information (Schedler 1999, 17). In other words, accountability contains elements of information, justification, and punishment (Lee and Yang 2007, 81).

From the perspective of a subject (actor), accountability indicates taking on responsibility for another (Mulgan 2001; Kim, No, and Lee, 2004, 269) through an official procedure. In this sense, the concept of accountability includes direction (for whom to be responsible), object (for what to be responsible), and nature (how to be responsible). This is described further in table 1.

Table 1. Accountability Index

\begin{tabular}{|c|c|c|}
\hline Classification & Index & Content \\
\hline \multirow[t]{4}{*}{$\begin{array}{l}\text { Direction of } \\
\text { accountability }\end{array}$} & $\begin{array}{l}\text { Upward } \\
\text { accountability }\end{array}$ & $\begin{array}{l}\text { - The activity records of the organization are periodically prepared and } \\
\text { submitted to higher organizations. } \\
\text { - Procedures and systems to reflect higher organizations' evaluations } \\
\text { and recommendations have been established. }\end{array}$ \\
\hline & $\begin{array}{l}\text { Downward } \\
\text { accountability }\end{array}$ & $\begin{array}{l}\text { - Systematic devices to grasp the preferences and needs of customers } \\
\text { (service consumers) have been designed. } \\
\text { - Procedures to collect and reflect the complaints raised by customers } \\
\text { (service consumers) have been prepared. }\end{array}$ \\
\hline & $\begin{array}{l}\text { Horizontal } \\
\text { accountability }\end{array}$ & $\begin{array}{l}\text {-W ork-related information and know-how are shared with individuals } \\
\text { or organizations conducting similar w ork. }\end{array}$ \\
\hline & $\begin{array}{l}\text { Inward } \\
\text { accountability }\end{array}$ & $\begin{array}{l}\text { - Efforts are made to share the vision, mission, and value of the } \\
\text { organization among the members. } \\
\text { - Uncontradictory designs of the vision, mission, value, work } \\
\text { implementation procedures, and evaluation procedures are available. }\end{array}$ \\
\hline \multirow[t]{3}{*}{$\begin{array}{l}\text { Subject of } \\
\text { accountability }\end{array}$} & $\begin{array}{l}\text { Process } \\
\text { accountability }\end{array}$ & $\begin{array}{l}\text { - The organization's internal decision-making processes are democratic. } \\
\text { - Established institutional devices and procedures exist to allow } \\
\text { customers (service consumers) external to the organization to } \\
\text { participate in the decision-making processes of the organization. } \\
\text { - The organization's work implementation processes are disclosed at all } \\
\text { times. }\end{array}$ \\
\hline & $\begin{array}{l}\text { Performance } \\
\text { accountability }\end{array}$ & $\begin{array}{l}\text { - Institutional devices exist to measure and evaluate the quality of } \\
\text { projects and programs. } \\
\text { - Efforts are made to enhance the quality of projects and programs, and } \\
\text { compensation systems exist to reward organization members who } \\
\text { produce concrete outcomes. } \\
\text { - Customer groups' satisfaction with projects and programs is measured. }\end{array}$ \\
\hline & $\begin{array}{l}\text { M oral/ethical } \\
\text { accountability }\end{array}$ & $\begin{array}{l}\text { - A charter of ethics has been established. } \\
\text { - A code of conduct has been established. }\end{array}$ \\
\hline
\end{tabular}




\begin{tabular}{|c|c|c|}
\hline Classification & Index & Content \\
\hline \multirow[t]{4}{*}{$\begin{array}{l}\text { Nature of } \\
\text { accountability }\end{array}$} & $\begin{array}{l}\text { Organizational } \\
\text { accountability }\end{array}$ & $\begin{array}{l}\text { - J ob descriptions for individual classes and duties in the organization } \\
\text { have been prepared. } \\
\text { - Criteria for selecting suitable personnel for given position classes and } \\
\text { duties have been prepared. } \\
\text { - Personnel management criteria are fair and transparent. } \\
\text { - Periodic internal/external audits are scheduled, including financial } \\
\text { audits relating to the works of the organization. } \\
\text { - Persons in charge of internal/external audits are experts } \\
\text { - Audit results are disclosed appropriately. }\end{array}$ \\
\hline & $\begin{array}{l}\text { Legal } \\
\text { accountability }\end{array}$ & $\begin{array}{l}\text { - Objectives, tasks, work procedures, and expected results and effects } \\
\text { of works are stipulated explicitly. } \\
\text { - M ethods for administration of punishment when the operation of the } \\
\text { organization has violated regulations are stipulated. }\end{array}$ \\
\hline & $\begin{array}{l}\text { Political } \\
\text { accountability }\end{array}$ & $\begin{array}{l}\text { - The organization's activity records are periodically prepared and } \\
\text { submitted to customer groups or their representatives. } \\
\text { - Procedures and methods are stipulated to impose liability when any } \\
\text { activity record of individuals or the organization is unsatisfactory or } \\
\text { involves errors. }\end{array}$ \\
\hline & $\begin{array}{l}\text { Moral } \\
\text { accountability }\end{array}$ & $\begin{array}{l}\text { - A charter of ethics has been established. } \\
\text { - A code of conduct has been established. }\end{array}$ \\
\hline
\end{tabular}

Accountability inevitably involves a certain direction, as it indicates one's obligation for a report to (and subsequent control by) another (Simey 1985). Edwards and Hulme's (1996) study on accountability of civic organizations provided four directions of accountability: upward, downward, horizontal, and inward. Upward accountability includes obligation to a higher authority on a hierarchical order. Downward accountability indicates obligation to serve recipients or represented groups. Horizontal accountability means obligation to peer groups, and inward accountability is concerned with organizational structure and management conditions, and accountability for the mission and value of an organization and its members.

The object of accountability can be divided into the moral and ethical values of organizational members (responsibility), work process (answerability), and performance (responsiveness). Whether individual or group, responsibility always includes the question "for what." Accountability inevitably involves specific content and an object of control. This corresponds to previously examined concepts of answerability, responsibility and responsiveness. What corresponds to answerability is control over the work process. According to Schedler $(1999,17)$, accountability is an act of providing information on one's tasks of the past, present, and future with responsibility for 
another person or organization, and this is premised on transparency of the work process through continued conversation and communication with the controlling authority and interested parties. What corresponds to responsiveness is performance, which has come to the forefront of the administration field along with governance and New Public Management.

Whether upward, downward, inward, or outward, having accountability means being responsible for process, customer satisfaction, and a specific outcome. Therefore, the concept of responsiveness that attentively detects and satisfies customer needs is naturally connected to performance and its control.

The concept of responsibility also contains moral and ethical values, which Lee K. (2005) termed subjective obligation. It indicates how much effort organizational members make to carry out their tasks and how honestly and accurately they endeavor to do their work.

Accountability can also be categorized as either organizational, legal, political, or moral (Gilbert 1969, 382-83 and Lee K. 2005, 42-46). Taking responsibility for another actor or group means that a specific rule and procedure exists to call a person to account. These pieces of research present the internal hierarchical order of an organization as the first element of a specific system of responsibility, which is present in conventional bureaucracy. Legal enforcement consists of elements such as office regulations, work process regulations, and rewards and penalties. Political control is exerted through a traditional decision-making structure of external higher authority or other peripherally acting groups. Moral control could be exerted, for example, by a comprehensive and voluntary code of ethics or behavior.

\section{ANALYSIS FRAMEWORK AND RESEARCH METHOD}

As research results accumulate, the concept of accountability continues to expand, evolving from answerability to include aspects of control, performance, responsibility, and responsiveness. As a result, the index of accountability has also diversified. Modern administration should have ethically and morally sound internal perceptions and motives (Lee K. 2005, 34-36) to faithfully carry out its obligation according to rules (this was usually referred to as "subjective obligation (responsibility)" in previous studies) that set out the responsibility for work outcome (performance) in terms of customer satisfaction and should conform to numerous control mechanisms.

However, these definitions and indexes are centered on a perspective of conventional management of bureaucracy rather than governance. The above discussions are based on the premise that the subject of all accountability is a single actor or group or 
organization, without referring to accountability among multiple actors or groups or organizations. Thus, the index might not be relevant in measuring and evaluating accountability in collaborative governance. The following section provides a glimpse of the concept and main characteristics of collaborative governance and examines why the conventional index of accountability might not be applicable to it. In addition, the research process and methodology are briefly described to develop an accountability index for collaborative governance.

\section{Collaborative Governance}

Governance is different from conventional bureaucracy in that it is a new ruling process that responds to changing circumstance (Rhodes 1997) and an interactive system that involves various stakeholders' participation, negotiation, conflict and collaboration (Kooiman 2003). Collaborative governance is characterized by participation of multiple actors, and it especially emphasizes mutual collaboration among different participants sharing common goals and tasks. Some key recent definitions are summarized below.

- Huxham (2000) defined collaborative governance as including participants from multiple organizations with shared tasks.

- Kim et al. (2002) defined collaborative governance on two levels. In a narrow sense, it is a type of system and adjustment that facilitates various participants to collaborate through voluntary and mutually beneficial principle of interdependence even without official authority. In a wider sense, it is a mutually collaborative new adjustment method that emerged with collapse of division between government-led public agencies and private agencies.

- Kooiman (2003) argued that no one actor can provide a fair and effective ruling in a diverse, dynamic, and complex social realm, and governability depends on the quality of interaction among various participants. Voluntary participation and collaboration are crucial elements in smooth interaction. Taking this a step further from interactive governance, Kooiman defined "socio-political governance" as "sharing a series of responsibility among nation, market and civic society," emphasizing responsibility and the collaborative aspect of governance. - Hong (2004) borrowed an argument of Streeck and Schmitter (1985) on the idea of community, market, and association as a principle for forming social order and distinguished between three types of governance: collaborative, hierarchical, and competitive. Collaborative governance indicates a problem-solving approach based on voluntary collaboration among central and local governments, nongovernmental organizations, and community residents, suggesting a highly interdependent collaboration for policy making. 
- Henton et al. (2008, 3-4) interpreted collaborative governance as combining the meanings of collaboration and governance. While governance indicates a process of adjustment that affects the decisions and behavior of the market, government, and civic society, collaboration involves various elements of society working toward a shared goal, based on the principle of reciprocity.

- According to Tang and Mazmanian (2008, 5), collaborative governance means the process of establishing, steering, facilitating, operating, and monitoring cross-sectoral organizational arrangements to address public policy problems that cannot be easily addressed by a single organization or the public sector. These arrangements are characterized by joint efforts, reciprocal expectations, and voluntary participation among formally autonomous entities, from two or more sectors - public, for-profit, and nonprofit - in order to leverage the unique attributes and resources of each. They also suggest that the collaborative process may span across one, several, or even all the stages of the public policy process-from formulation, enactment, and implementation to evaluation and feedback.

- Kim $(2008,51)$ borrowed Gray's $(1985,1989)$ and Wondolleck and Yaffe's (2000) concepts of collaboration and defined collaborative governance as a joint decision-making process that collects and distributes visible resources (capital, labor) and invisible resources (understanding, information, authority) and develops a shared vision in order to solve common issues.

- Park $(2008,123)$ argued that a single focused decision-making process in administrative bureaucracy fails to ensure timely problem solving as the information society has brought about rapid social changes, complexity, diversity, and dynamism. Collaborative governance is a solution to bring a decisionmaking body closer to a field in order to promptly respond to a problem and to reduce the cost of switching to "decision-making mode for a particular problem." Collaborative governance applies to an interactive relationship (either collaboration or confrontation) between public administration and civic society, instead of regarding them as unitary or dual entities.

Collaborative governance, based on voluntary participation and mutual collaboration, is clearly different from conventional bureaucracy in terms of organizational structure, work process, and responsibility (Kim 2008, 51). First of all, the structure of collaborative governance is problem-solving-oriented and thus amorphous and atypical compared to conventional bureaucracy. Also, it depends on a horizontal relationship rather than hierarchical order and is more outward-looking than internally directed. Instead of the closed self-interest of bureaucracy, collaborative governance pays attention to the environment, human rights, freedom, and peace, and relies on knowledge, information, problem-solving ability, and leadership for organizational management rather than on official position or authority. In terms of responsibility, it aspires 
to procedural control through conversation and communication rather than post-evaluation of conformity or observation, ultimately pursuing a performance-oriented responsibility structure. Under collaborative governance, collaboration, shared vision, and trust-based long-term relationships and community relationships prevail over competition, conflict, or opportunistic attitudes (table 2).

Table 2. Features of Conventional Bureaucracy and Collaborative Governance

\begin{tabular}{|c|c|c|c|}
\hline \multicolumn{2}{|l|}{ Category } & \multirow{2}{*}{$\begin{array}{l}\text { Conventional bureaucracy } \\
\text { Geographical characteristics, } \\
\text { functions, customers, } \\
\text { and outputs }\end{array}$} & \multirow{2}{*}{$\begin{array}{l}\text { Collaborative governance } \\
\text { Problem solving }\end{array}$} \\
\hline $\begin{array}{l}\text { Organizational } \\
\text { structure }\end{array}$ & Structural criteria & & \\
\hline & Organizational structure & Vertical & Horizontal \\
\hline & Managementfocus & Internal control & $\begin{array}{l}\text { Management of external } \\
\text { environment }\end{array}$ \\
\hline & Management method & $\begin{array}{l}\text { Fragmented approach } \\
\text { to problems }\end{array}$ & $\begin{array}{l}\text { Comprehensive and } \\
\text { sustainable development }\end{array}$ \\
\hline & $\begin{array}{l}\text { Basic management } \\
\text { principles }\end{array}$ & $\begin{array}{l}\text { Order, control, } \\
\text { and authority }\end{array}$ & $\begin{array}{l}\text { Ideas, information, problem- } \\
\text { solving ability, commitment, } \\
\text { passion, humane attitude, } \\
\text { leadership }\end{array}$ \\
\hline \multirow[t]{3}{*}{ Work process } & $\begin{array}{l}\text { Subject and object } \\
\text { of responsibility }\end{array}$ & Separated & Not separated \\
\hline & Goal-achieving approach & Competition & Collaboration \\
\hline & $\begin{array}{l}\text { Responsibility } \\
\text { mechanism }\end{array}$ & Rule-oriented & Performance-oriented \\
\hline
\end{tabular}

Source: Adapted from Kim, No, and Lee 2004.

Thus, collaborative governance is a system that pursues better performance through mutual collaboration, sharing of rights, and joint decision making based on voluntary participation of various actors. To ensure accountability of collaborative governance, an interactive control mechanism is required rather than a one-way approach. The control should be over interrelationships among various participants and their groups instead of a particular actor or a group. Without control over relationships among multiple interactive actors, control as well as the entire governance system may not be highly efficient.

From a perspective of conventional control, it is hard to address the collaboration and accountability that characterize governance. While conventional control is a device to improve the answerability, responsibility, performance, and responsiveness 
of a particular actor or group or organization, in collaborative governance, a control method needs to be developed to improve collaborative relationships among multiple participants and their groups or organizations to ensure accountability. For collaborative governance, therefore, accountability for an internal collaborative relationship is even more important than accountability for the outside world. The central argument of this study is that the accountability index for collaborative governance should shift its focus to accountability for collaboration instead of emphasizing its direction, object, and nature.

\section{Governance Structure of Korean Community Centers}

Since 1999, as part of its effort to create a smaller government, the Korean government has worked on transforming the functions of district (eup/myeon/dong) offices, which used to provide field services for local administration. Due to emerging needs for efficient and effective service provision and delivery, such tasks as social welfare and safety management were transferred to superior institutions at the municipal (gun and $g u$ ) levels. The function of district (eup/myeon/dong) offices, renamed as residents' centers, was then limited to provision of traditional services for civil affairs.

This change provided a foundation to establish self-governing institutions with the participation of community residents and with extra space and staff: community centers. ${ }^{1}$ This study will review the organizational and operational states of community centers while retracing the structure of collaborative governance-arguing, based on the characteristics reviewed in table 2 , that community centers are an example of collaborative governance.

\section{Organizational Structure}

\section{Structural Criteria}

Unlike in the West, Korean community centers were not organized spontaneously from the bottom up, but from the top down as a part of a public administration reform (Lee S.M. 2005). Nevertheless, the concept of community centers is similar to that of community centers in Anglo-American societies and citizens' centers in Japan (Yoo 2004, 7-9). Kim and Ryoo (2008, 86) also defined Korean community centers as selfdeterminant organizations. This is because Korean community centers provide oppor-

1. Legal language governing this issue can be found in Article 8 of the Municipal Self-Governing Law, the Enforcement Ordinance Article 8 of the same law, and the Standard for Establishment and Operation of Community Centers. 
tunities for residents to solve local problems by themselves, having the attributes of administrative organizations to provide specific public services while also having autonomous functions allowing residents to participate in managing collective affairs. Thus the authors argue that Korean community centers are similar to those in AngloAmerican societies in that they function as a tribunal for discussion and interaction by local residents.

\section{Organizational Structure}

Community centers can be differentiated from traditional bureaucratic systems above all in their horizontal form of organization. The heads of district offices (residents' centers) are expected to take charge of the operation of community centers as well, but in that regard they are obliged to systematically consult the community council.

Community councils deliberate on matters regarding (1) the installation and operation of community centers; (2) the improvement of residents' culture, welfare, and benefits; (3) the strengthening of residents' autonomous activities, (4) the formation of regional communities, and (5) other matters necessary for the operation of community centers. Thus, community councils are the practical operators of community centers.

Each community council is composed of at least 15 , but not more than 30 , members and may not have more than three advisers. The chairperson and the vice chairperson are elected by council members but cannot be civil servants (including local assemblymen). Council membership is an unpaid honorary post, although actual expenses may be compensated if the budget permits. The term of office is two years, and council members may be reappointed.

This means that, while residents' centers maintain the organizational structure of a traditional bureaucracy system, community centers can be seen as having a representative governance structure, raising the necessity of collaboration between government and citizens.

\section{Management Focus}

The ultimate objectives of community centers are to enhance the quality of life of residents by operating cultural and social (welfare) facilities and programs for residents and to serve the role of a central body to enhance the autonomy of residents through their direct participation. Therefore, unlike the residents' centers in charge of traditional public administrative functions for civil affairs (such as issuance of documents, social welfare, civil defense and disaster management, and provision of public administrative information), community centers are required to conduct the functions outlined in table 3. 
Table 3. Community Center Functions

\begin{tabular}{ll}
\hline Functions & Examples of services \\
\hline Residents' autonomy & $\begin{array}{l}\text { Discussion of regional issues, improvement of community environment, } \\
\text { disaster prevention }\end{array}$ \\
\hline Culture and leisure & Local cultural events, hobby classes, physical exercise activities, exhibitions \\
\hline Citizen educ ation & Culture lectures, youth classes, community culture research groups \\
\hline Assistance to residents & Provision of everyday life information, flee markets, meeting rooms \\
\hline Regional welfare & Health improvement, youth study room, community library \\
\hline Community development & House front cleaning, mutual assistance, youth guidance \\
\hline
\end{tabular}

However, the most important function of community centers is the promotion of a sense of community among residents by providing a stage for exchanges and meetings and a social education function. These functions are intended to foster public spirit, thereby overcoming the alienation, individualization, and anonymity of residents (Lee 2000). Unlike the bureaucracy system, which prioritizes internal control in organizations, community centers emphasize management of the external environment.

\section{Management Method}

Community centers are expected to pursue sustained development through longterm and comprehensive problem solving rather than to respond to fragmentary and immediate problems. These characteristics are revealed more clearly when categorizing various community center programs by type. In 31,752 programs implemented by community centers across the country as of March 2008, the number of culture and leisure programs was 16,829 (53.0 percent), constituting a major part of the program, followed by 5,815 citizen education programs (18.4 percent). Educational programs accounted for 71.4 percent of the community programs (internal data of The Ministry of Public Administration Safety, 2008).

\section{Basic Management Principles}

Community centers have the motto of self-determination and voluntary operation through participation of local residents led by community councils. Therefore, community centers that represent residents' needs while forming direct contact points with residents are characterized by accurate knowledge and information on pending problems, problem-solving ability, and leadership, rather than reliance on official positions or authority. These characteristics can be easily identified from the testimonies of many participants, indicating that dialogue in the course of operation is essential for community centers to achieve their goals. ${ }^{2}$ 


\section{Work Process}

\section{Subject and Object of Responsibility}

The ordinance governing community center installation and operation involves four categories of actors: heads of residents' centers (eup/myeon/dong offices), civil servants responsible for community centers, chairpersons of community councils and its members. The heads of residents' centers (eup/myeon/dong offices) are also responsible for the operation of community centers and are obligated to report matters to higher organizations. They also have the right to appoint members of community councils and civil servants responsible for community centers. The chairpersons of community councils represent the councils and have the right to hold meetings with civil servants and council members.

This ordinance stipulates the legal accountability of these four categories of actors. Thus, discussions of the accountability of community centers can be accomplished by focusing on these four subjects. However, there is no clear definition of the subjects and objects of responsibility in the operation of community centers. Although the heads of eup/myeon/dong offices are purported to be responsible for community centers, community councils have no concrete tools or measures to call the heads of eup/myeon/dong offices to account, and the heads of eup/myeon/dong offices also cannot call community councils to account in any way.

\section{Goal-Achieving Approach}

The operation of community centers is thus based on the principle of collaboration rather than competition. Importance is attached to mutual collaboration on common visions rather than conflicts and long-term transaction relationships; relationships are seen as communities and based on trust rather than on opportunistic calculations. Indeed, the majority of the heads of community centers and the members of community councils have testified that the relationships between the two parties are premised on collaboration and trust rather than competition and conflict; they make efforts to provide opportunities for personal contacts and dialogue in everyday life as well as official meetings and procedures. In short, the concerned parties perceive and practice dialogues and collaboration as practical tools to accomplish their common goals, as there is no other internal control tool apt to enhance the responsibility of each party.

2. These statements are based on interviews with four chairpersons of community councils and three heads of residents' centers. 


\section{Responsibility Mechanism}

Since the subjects and the objects of responsibility are not separated, the operation of community centers is based on a process of mutual control. The method of accomplishing objectives is also based on collaboration rather than on competition. This system is clearly distinguished from the traditional control mechanism of bureaucratic systems: community centers are based on the principle of dialogue and communication rather that ex post facto control according to compliance or noncompliance with regulations. Consequently, the responsibility structure of community centers is performance-oriented rather than regulation-oriented.

For the heads of community centers, who are professional civil servants, the outcomes of their community center activities are evaluated and directly linked to incentives such as promotions. But for the members of community councils, their membership provides them with experience that can help them strive for electoral positions such as gu assemblymen or members of the provincial or national assembly. Therefore, it seems that concrete outcomes that satisfy the necessities and desires of residents through the mediation of collaborative relationships are becoming increasingly common interests of the two groups, and responsibility for outcomes is perceived as more important than responsibility for processes.

This observation also seems to be derived from the community centers' outcomeoriented responsibility structure, which differentiates between the subject and the object of responsibility. This structure is based on collaborative relationships because collaboration is a major method of accomplishing objectives; the concrete outcomes resulting from collaboration can be used to measure and evaluate the degree of collaboration.

\section{Research Method}

In the previous sections, community centers have been shown to be a case of collaborative governance involving government representatives and citizens, since, although they use the physical spaces and budgets provided by the government, decisions are jointly made by residents and civil servants and decisions are jointly executed by civil servants, residents, and citizen groups. In an attempt to derive a measure to ensure the accountability of collaborative governance, this study employed the following procedures, using community centers as empirical cases in order to derive indexes for the accountability of collaborative governance.

First, the 23 items in table 1, which were developed as an accountability index for conventional bureaucracy, were converted into a survey to examine what the important accountability factors are for field actors at community centers and to measure the 
importance of each (see table 4). ${ }^{3}$ The assumption was that the factors perceived as most significant in explaining accountability of community centers can also be regarded as the accountability index for collaborative governance. Even though these 23 items were developed from a conventional perspective of bureaucracy, they are a valid index as they work as a mechanism for mutual control within collaborative governance arrangements. In other words, whether they refer to conventional bureaucracy or collaborative governance, the concept and attributes (direction, object and nature) of accountability remain identical, and so what matters is to elucidate which specific factors are more decisive in the case of collaborative governance.

Table 4. Accountability Index for Community Centers

\begin{tabular}{llll}
\hline Category & Index & Description & Survey item \\
\hline Direction & $\begin{array}{l}\text { Upward } \\
\text { accountability }\end{array}$ & $\begin{array}{l}\text { Does the community center submit performance reports } \\
\text { to a higher authority (municipal, gun, gu office)? }\end{array}$ & a01 \\
\cline { 3 - 4 } & & $\begin{array}{l}\text { Does the community center reflect the opinions and } \\
\text { evaluations of a higher authority (municipal, gun, gu office)? }\end{array}$ & a02 \\
\cline { 2 - 4 } & $\begin{array}{l}\text { Downward } \\
\text { accountability }\end{array}$ & $\begin{array}{l}\text { Does the community center conduct a survey before or } \\
\text { after a project in order to examine residents' needs and } \\
\text { preferences? }\end{array}$ & a03 \\
\cline { 2 - 4 } & $\begin{array}{l}\text { Does the community center make continued efforts to } \\
\text { examine residents' complaints and redress problems? }\end{array}$ & a04 \\
\cline { 2 - 4 } & $\begin{array}{l}\text { Horizontal } \\
\text { accountability }\end{array}$ & $\begin{array}{l}\text { Does the community center have official or unofficial } \\
\text { information sharing netw orks with other centers or } \\
\text { councils? }\end{array}$ & a05 \\
\cline { 2 - 4 } $\begin{array}{l}\text { Inward } \\
\text { accountability }\end{array}$ & $\begin{array}{l}\text { Does the community center have a well-organized annual } \\
\text { plan? }\end{array}$ & a06 \\
\cline { 2 - 4 } & $\begin{array}{l}\text { Do members of the community council share the annual } \\
\text { plan with the community? }\end{array}$ & a07 \\
\hline
\end{tabular}

3. Because index 11 in table 1 (moral accountability) overlapped with index 7 (moral/ethical accountability), index 11 was omitted from table 5. The conversion of the general accountability indexes in table 1 into the accountability indexes for community centers in table 5 was based on in-depth interviews with the heads of eup/myeon/dong offices, members of community councils participating in the operation of community centers, and residents, while referring to earlier studies on community centers. The in-depth interviews were conducted with the heads and members of community councils, first-line heads of dong offices, responsible civil servants, and 12 residents, for a total of 14 hours and 30 minutes. 


\begin{tabular}{|c|c|c|c|}
\hline Category & Index & Description & Survey item \\
\hline \multirow[t]{7}{*}{ Object } & \multirow[t]{3}{*}{$\begin{array}{l}\text { Process } \\
\text { accountability }\end{array}$} & $\begin{array}{l}\text { Is the decision-making process of the community center } \\
\text { (council) fair and transparent? }\end{array}$ & $\mathrm{a} 08$ \\
\hline & & $\begin{array}{l}\text { Does the community center (council) regularly notify } \\
\text { community residents of its decisions? }\end{array}$ & a09 \\
\hline & & $\begin{array}{l}\text { Does the community center (council) consider residents' } \\
\text { needs and preferences in the decision-making process? }\end{array}$ & a10 \\
\hline & \multirow[t]{2}{*}{$\begin{array}{l}\text { Performance } \\
\text { accountability }\end{array}$} & $\begin{array}{l}\text { Does the community center (council) grant proper rewards } \\
\text { to council members or volunteers for excellent performance? }\end{array}$ & al1 \\
\hline & & $\begin{array}{l}\text { Does the community center (council) receive proper rewards } \\
\text { from a higher authority (municipal, gun, or gu office) for } \\
\text { excellent performance? }\end{array}$ & a12 \\
\hline & \multirow{2}{*}{$\begin{array}{l}\text { Accountability } \\
\text { for moral and } \\
\text { ethical values }\end{array}$} & $\begin{array}{l}\text { Does any community council member pursue personal } \\
\text { interests at work? }\end{array}$ & a13 \\
\hline & & $\begin{array}{l}\text { Is there a measure to prohibit people from participating in the } \\
\text { council in pursuit of personal interests? }\end{array}$ & a14 \\
\hline \multirow[t]{9}{*}{ Nature } & \multirow[t]{2}{*}{$\begin{array}{l}\text { Organizational } \\
\text { accountability }\end{array}$} & $\begin{array}{l}\text { Do community council members actively participate in } \\
\text { council activities? }\end{array}$ & a15 \\
\hline & & $\begin{array}{l}\text { Is there a measure to regulate council members who neglect } \\
\text { council activities? }\end{array}$ & a16 \\
\hline & \multirow[t]{2}{*}{$\begin{array}{l}\text { Legal } \\
\text { accountability }\end{array}$} & $\begin{array}{l}\text { Are the obligations and tasks of each council member clearly } \\
\text { described? }\end{array}$ & a17 \\
\hline & & $\begin{array}{l}\text { Does the community council regulate violations of tasks and } \\
\text { work processes by council members? }\end{array}$ & a18 \\
\hline & \multirow[t]{5}{*}{$\begin{array}{l}\text { Political } \\
\text { accountability }\end{array}$} & $\begin{array}{l}\text { Does the community council endeavor to actively } \\
\text { communicate with local residents and reflect their opinions? }\end{array}$ & a19 \\
\hline & & $\begin{array}{l}\text { In case residents have complaints about the work of the } \\
\text { community council, is there a way to appeal to a higher } \\
\text { authority (municipal, gun, or gu office)? }\end{array}$ & a20 \\
\hline & & $\begin{array}{l}\text { Is there a specific standard for appointing members to the } \\
\text { community council? }\end{array}$ & a21 \\
\hline & & $\begin{array}{l}\text { Is the process of appointing council member fair and } \\
\text { transparent? }\end{array}$ & $a 22$ \\
\hline & & $\begin{array}{l}\text { Is the expertise of community council members sufficiently } \\
\text { considered in making appointments? }\end{array}$ & a23 \\
\hline
\end{tabular}

Second, an EFA of the 23 items, as shown in table 4, was conducted to eliminate items with little significance and to facilitate the analysis. How these 23 items could be regrouped was then examined. By interpreting their implications, an accountability 
index was organized that should be taken into consideration in assessing performance of collaborative governance. Previous studies on case examples and interviews with the chief of the eup/myeon/dong office, community council members, and local residents were also taken into account.

\section{ANALYSIS}

\section{Descriptive Statistics}

The survey was conducted with two major groups involved with the community centers: the chiefs of the eup/myeon/dong offices and their field officers in one group, and the heads and members of the community councils in the other. A self-administered questionnaire was used. Four copies of the survey (one for the chief of the eup/myeon/dong office, one for the field officer, one for the head of the community council, and one for a council member) were e-mailed to 300 community centers out of 2,600 in the country, sampling different geographic locations (including Jeju Island) and sizes (metropolitan city and province).

Out of 1,200 questionnaires distributed, 969 were returned, of which eight were eliminated for incompleteness. In terms of jobs, 235 respondents (24.4 percent) were chiefs of eup/myeon/dong, 210 (21.9 percent) were heads of community councils, 223 (23.2 percent) were members of a council, and 293 (30.5 percent) were public servants, which showed quite an even distribution (table 5).

Table 5. Demographic Attributes of Survey Respondents

\begin{tabular}{|c|c|c|c|c|c|}
\hline Category & & Frequency (\%) & Category & & Frequency $(\%)$ \\
\hline \multirow[t]{2}{*}{ Gender } & Male & $718(74.7)$ & \multirow{4}{*}{$\begin{array}{l}\text { Educational } \\
\text { background }\end{array}$} & High school diploma & $305(31.7)$ \\
\hline & Female & $243(25.3)$ & & Vocational college diploma & $156(16.3)$ \\
\hline \multirow[t]{6}{*}{ Age } & Under 30 & $27(2.8)$ & & Four-year college diploma & $464(48.3)$ \\
\hline & $30-39$ & 132 (137) & & Graduate school or higher & $36(3.7)$ \\
\hline & & | & \multirow[t]{4}{*}{ Position } & Chief of eup/myeon/dong office & $235(24.4)$ \\
\hline & $40-49$ & $227(23.7)$ & & Head of community council & $210(21.9)$ \\
\hline & $50-59$ & $470(48.9)$ & & M ember of community council & $223(23.2)$ \\
\hline & Over 60 & $105(10.9)$ & & Field officer & $293(30.5)$ \\
\hline
\end{tabular}

Out of 23 items addressing accountability of the community center, respondents gave a positive reply (average score over 3.0) to 14 items. Item a13 (which measured 
accountability for moral and ethical values) showed a negative perception, with an average score below 2.0; however, since the lower score indicates higher accountability for moral and ethical values, the result actually suggests a positive perception that can be converted to an average score over 3.0. For items a11 and a12 (which measured accountability for performance), the average score was below 3.0; 46.7 percent and 41.5 percent respectively of the respondents gave a negative reply (table 6).

Table 6. Average and Standard Deviation for Each Survey Item

\begin{tabular}{llcc}
\hline Survey item & Index & Average $(\mathrm{N}=091)$ & Standard deviation \\
\hline a01 & Upward accountability 1 & 3.41 & .638 \\
a02 & Upward accountability 2 & 3.36 & .575 \\
a03 & Downward accountability 1 & 2.89 & .748 \\
a04 & Downward accountability 2 & 3.37 & .597 \\
a05 & Horizontal accountability & 3.00 & .709 \\
a06 & Inward accountability 1 & 3.31 & .638 \\
a07 & Inward accountability 2 & 3.21 & .662 \\
a08 & Accountability for process 1 & 3.51 & .554 \\
a09 & Accountability for process 2 & 3.00 & .694 \\
a10 & Accountability for process 3 & 3.15 & .596 \\
a11 & Accountability for performance 1 & 2.57 & .798 \\
a12 & Accountability for performance 2 & 2.61 & .785 \\
a13 & Accountability for moral and ethical values 1 & 1.46 & .653 \\
a14 & Accountability for moral and ethical values 2 & 3.11 & .841 \\
a15 & Organizational accountability 1 & 3.06 & .657 \\
a16 & Organizational accountability 2 & 2.61 & .719 \\
a17 & Legal accountability 1 & 2.84 & .731 \\
a18 & Legal accountability 2 & 2.71 & .761 \\
a19 & Political accountability 1 & 3.14 & .660 \\
a20 & Political accountability 2 & 2.54 & .741 \\
a21 & Legal accountability 3 & 3.12 & .685 \\
a22 & Political accountability 3 & 3.35 & .612 \\
a23 & Organizational accountability 3 & 2.87 & .707 \\
\hline
\end{tabular}

Note: The Likert 4 -point scale was used ( $1=$ not at all to $4=$ very much so).

\section{Exploratory Factor Analysis-Index for Collaborative Governance}

Based on the survey results for the 23 items, this study conducted EFA in order to identify factors that affected the accountability of the community centers. The method of principal component analysis was adopted to contain the maximum information with minimal numbers. For rotation of factors, varimax rotation was used because it 
maintains mutual independence of factors.

Five factors were extracted with eigenvalues over 1.0, and 20 variables were finalized in consideration of the commonality and confidence coefficient of each item of identified factors.

The KMO (Kaiser-Meyer-Olkin) value, which shows how much of a correlation between pairs of variables can be explained by other variables, was rather high (.906). The value of the Bartlett test of sphericity, which represents fitness of factor analysis, was $5,759.721$, with a significance probability of $p=.000$. This suggests that the use of factor analysis was adequate to identify accountability items of collaborative governance. Next, this study conducted reliability analysis for factors that considered each item of the survey. In terms of Cronbach's $\alpha$ value, factor 1 (.813), factor 2 (.729), and factor 3 (.740) showed values higher than 0.7, while factor 4 (.688) and factor 5 (.643) showed values over 0.6. This indicates that the identified factors have high reliability (table 7).

Table 7. Exploratory Factor A nalysis

\begin{tabular}{lccccc}
\hline Survey item & Factor 1 & Factor 2 & Factor 3 & Factor 4 & Factor 5 \\
\hline a10 & .680 & .163 & .121 & .160 & .008 \\
a09 & .665 & .141 & .209 & .011 & .220 \\
a07 & .651 & .155 & .286 & .043 & -.045 \\
a06 & .600 & .078 & .099 & .229 & -.052 \\
a04 & .561 & .166 & .057 & .406 & -.208 \\
a05 & .558 & .164 & .065 & .217 & .094 \\
a08 & .526 &. .012 & .443 & .059 & -.239 \\
a19 & .514 & .400 & .271 & .137 & -.052 \\
a18 & .121 & .736 & .153 & .035 & .055 \\
a16 & .190 & .725 & .077 & -.006 & .003 \\
a20 & .103 & .610 & .092 & .087 & .187 \\
a17 & .407 & .486 & .274 & -.047 & -.004 \\
a14 & .060 & .468 & .142 & .208 & -.440 \\
a15 & .378 & .442 & .322 & .086 & -.070 \\
a22 & .214 & .143 & .785 & .152 & -.098 \\
a21 & .160 & .188 & .747 & .081 & .016 \\
a23 & .299 & .273 & .598 & .023 & .141 \\
a01 & .163 &. .009 & .057 & .809 & -.054 \\
a02 & .249 & .034 & .172 & .729 & .066 \\
a03 & .338 & .270 & -.104 & .387 & .282 \\
a13 & .148 & -.089 & -.227 & -.172 & .640 \\
a11 & .145 & .264 & .194 & .234 & .593 \\
a12 & .054 & .289 & .227 & .364 & .499 \\
Eigenvalue & 3.637 & 2.747 & 2.381 & 1.959 & 1.528 \\
Variance ratio & $31.432 \%$ & $8.014 \%$ & $7.028 \%$ & $5.311 \%$ & $5.043 \%$ \\
Accumulated variance ratio & $31.432 \%$ & $39.446 \%$ & $46.474 \%$ & $51.785 \%$ & $56.828 \%$ \\
Cronbach's $\alpha$ & .813 & .729 & .740 & .668 & .643 \\
\hline KM0 scale $=.906 ;$ Bartlett test of sphericity $=5759.721(p=.000)$ & & & \\
& & & & & \\
\hline
\end{tabular}


Five accountability factors identified through EFA are different from the accountability factors for the foundation of bureaucratic management that the initial research framework suggested (see table 1). Table 8 shows attributes of measurement items grouped within the five factors. Factor 1 emphasizes communication with local residents in the decision-making process to improve transparency and democracy as well as to reflect people's complaints. Factor 2 is related to the clarity of the relevant law, enforcement decree, and regulation. Factor 3 demonstrates representativeness and expertise of council members. Factor 4 includes responses to local residents' opinions and evaluations. Factor 5 addresses the reward and incentive system, which shows the importance of a reward from a higher authority or an inside reward for members of a council or volunteers.

Table 8. Regrouping Accountability Index for Collaborative Governance

\begin{tabular}{|c|c|c|}
\hline Survey item & Description & Index \\
\hline $\begin{array}{l}\mathrm{a} 10 \\
\mathrm{a} 09 \\
\mathrm{a} 07 \\
\mathrm{a} 06 \\
\mathrm{a} 04 \\
\mathrm{a} 08 \\
\mathrm{a} 19\end{array}$ & $\begin{array}{l}\text { - Transparency and democracy of decision-making process } \\
\text { - Effort to communicate with local residents in decision-making process } \\
\text { - Communication based on transparent and democratic decision-making process }\end{array}$ & Factor 1 \\
\hline $\begin{array}{l}\text { a18 } \\
\text { a16 } \\
\text { a20 } \\
\text { a17 } \\
\text { a14 } \\
\text { a15 }\end{array}$ & $\begin{array}{l}\text { - Direct/indirect control (sanction) power of local residents } \\
\text { - Clear desc ription of council members' tasks and work process } \\
\text { - Obligation of council members for active participation and pursuit of public interest } \\
\text { - Clarity of regulation and rules }\end{array}$ & Factor 2 \\
\hline $\begin{array}{l}\text { a22 } \\
\text { a21 } \\
\text { a23 }\end{array}$ & - Representativeness and expertise of community council members & Factor 3 \\
\hline $\begin{array}{l}\mathrm{a} 01 \\
\mathrm{a} 02 \\
\mathrm{a} 03\end{array}$ & $\begin{array}{l}\text { - Evaluation and feedback on council activities by local residents and higher authority } \\
\text { - Performance management }\end{array}$ & Factor 4 \\
\hline $\begin{array}{l}\text { a11 } \\
\text { a12 }\end{array}$ & $\begin{array}{l}\text {-Scope of achieved outc ome subject to official critic ism or commendation for } \\
\text { collaborative accomplishment } \\
\text { - Positive/negative incentives for voluntary collaboration } \\
\text { - Reward and incentive system }\end{array}$ & Factor 5 \\
\hline
\end{tabular}




\section{DISCUSSION: ASSESSING ACCOUNTABILITY OF COLLABORATIVE GOVERNANCE}

The implication of these factors becomes clear when examined in light of characteristics of collaborative governance. ${ }^{4}$ All five factors are either directly or indirectly connected to the structure, process, and outcome of collaboration, which are the three main attributes of collaborative governance (table 9).

Table 9. Accountability Index for Collaborative Governance

\begin{tabular}{|c|c|c|}
\hline Category & Index & Description \\
\hline \multirow[t]{2}{*}{$\begin{array}{l}\text { Accountability } \\
\text { for structure }\end{array}$} & $\begin{array}{l}\text { Clarity of law and regulation } \\
\text { (factor 2) }\end{array}$ & $\begin{array}{l}\text { Direct/indirect control (sanction) pow er of local } \\
\text { residents } \\
\text { Clear description of tasks and work process for } \\
\text { community council members } \\
\text { Obligation of the council members to active } \\
\text { participation and pursuit of public interest } \\
\text { Clarity of laws and regulations }\end{array}$ \\
\hline & $\begin{array}{l}\text { Representativeness and } \\
\text { expertise of community } \\
\text { council members (factor } 3 \text { ) }\end{array}$ & $\begin{array}{l}\text { Representativeness of council members } \\
\text { Expertise of council members }\end{array}$ \\
\hline $\begin{array}{l}\text { Accountability } \\
\text { for process }\end{array}$ & $\begin{array}{l}\text { Communication with local } \\
\text { residents through transparent } \\
\text { and democratic decision- } \\
\text { making process (factor } 1 \text { ) }\end{array}$ & $\begin{array}{l}\text { Transparency of decision-making process } \\
\text { Democracy of decision-making process } \\
\text { Effort to communicate with local residents in decision- } \\
\quad \text { making process }\end{array}$ \\
\hline \multirow[t]{2}{*}{$\begin{array}{l}\text { Accountability } \\
\text { for outcome }\end{array}$} & $\begin{array}{l}\text { Performance management } \\
\text { (factor 4) }\end{array}$ & $\begin{array}{l}\text { Evaluation and feedback for performance by local } \\
\text { residents and higher authority }\end{array}$ \\
\hline & $\begin{array}{l}\text { Reward and incentive system } \\
\text { (factor 5) }\end{array}$ & $\begin{array}{l}\text { Scope of achieved joint outc ome subject to official } \\
\text { critic ism or commendation for collaborative } \\
\text { accomplishment } \\
\text { Positive/negative incentives for voluntary collaboration }\end{array}$ \\
\hline
\end{tabular}

4. Previous studies on collaborative governance do not provide consistent definitions of the concept of collaboration. The concept has been developed more actively in the fields of organizational relations (Warren et al. 1975; Ring and Van de Ven 1994; Alexander 1995; Tang and Mazmanian 2008), networks (Alter and Hage 1993; O'Toole 1997; O'Toole, Meier, and Nicholson-Crotty 2005; Powell 1990), and group behavior (Olson 1971; Ostrom 1990). This study defines collaboration as a collective behavior pattern that is the opposite of noncollaboration and a process that aggregates private interests and preferences into collective choices. Noncollaboration is defined as a process of competition by multiple actors based on their respective interests and preferences to vie for a goal or tool. 


\section{Structure}

The structure of collaborative governance is relatively amorphous compared to that of conventional bureaucracy (Kim 2008, 51). The reason for this stems from the inherent nature of collaborative governance, which involves decentralization of power and joint decision making as well as the participation of multiple actors (Tang and Mazmanian 2008 , 5). In order to ensure accountability for the effective operation of a governance system, legal and systematic devices should be clear enough to dissuade conflict as much as possible, while promoting collaboration. As supporters of neo-institutional analysis claim, laws and regulations are social mechanisms to predetermine the behaviors and interactions of all the involved actors. It is also necessary to examine whether representatives of particular interest groups have sufficient expertise and whether their authority is acknowledged by relevant groups. Participation of multiple stakeholders comes in the form of indirect participation in a modern social structure; without recognized representativeness of agents, the foundation of collaborative governance may be weakened. It is equally important to ensure that these representatives have solid expertise in order to understand and reflect local residents' needs and ideas.

\section{Process}

Collaborative governance is an interactive system and process based on the principle of interdependence (Kim et al. 2002; Hong 2004; Suh and Min 2005). Presumably, the accountability of collaborative governance increases if the decision-making process is transparent and democratic and communication is active to examine and reflect local peoples' needs and demands, as they are the primary consumers of goods and services that collaborative governance produces. The fairer the process of collecting opinions from multiple participants, the more collaborative the interaction becomes to reach a shared goal.

\section{Outcome}

The main mechanism of collaborative governance is mutual collaboration to solve shared problems and achieve shared goals (Henton et al. 2008, 3-4), and such an effort is expected to provide prompt and more effective solutions by reducing the cost of the decision-making process (Park 2008, 123). That is, the collaborative process and the democratic nature of collaborative governance are not only valued for their democratic nature but are also believed to yield more effective and efficient outcomes than the vertical decision making of a conventional bureaucracy. In discussing the accountability 
of collaborative governance, accountability for outcome (performance) emerges as a critical factor, which can be facilitated by designing and implementing performance management and a proper reward and incentive system.

\section{ENSURING ACCOUNTABILITY OF COLLABORATIVE GOVERNANCE IN KOREAN COMMUNITY CENTERS}

This study conducted an EFA for 23 items from 10 accountability indexes that were developed from the perspective of conventional bureaucracy and compressed them into five factors in order to maximize the variation of variables (see table 7). The factors that are crucial for Korean community centers that have adopted collaborative governance are (1) transparent and democratic decision-making, (2) clarity of laws and regulations, (3) representativeness and expertise of community council members, (4) performance management, and (5) reward and incentive system.

This study also analyzed differences that could affect perceptions of the importance of these five factors. To this end, it divided survey respondents into two sets of groups, one representing function and the other location-public participants (heads of eup/myeon/dong offices and civil servants) and civil participants (heads and members of community councils), and city and non-city community centers-and conducted independent sample t-tests on these two groups. The results suggested that both differences should be considered when developing accountability measurement indexes.

\section{Differences between Public and Civil Groups}

The public and civil groups perceived different levels of importance in three out of five factors: clarity of laws and regulations (factor 2), performance management (factor 4), and rewards and incentives (factor 5). Results are reviewed in more detail in table 10.

Table 10. Differences betw een Public and Civil Groups in Perceptions of Factors Affecting the Accountability of Collaborative Governance (independent sample t-test)

\begin{tabular}{cccccc}
\hline \multirow{2}{*}{ Factor } & \multicolumn{2}{c}{ Levene's equal variance test } & & \multicolumn{2}{c}{ t-test for the sameness of means } \\
\cline { 2 - 3 } \cline { 5 - 6 } & $\mathrm{F}$ & $\mathrm{p}$ & & $\mathrm{t}$ & $\mathrm{p}$ \\
\hline Factor 1 & 0.606 & .437 & & -1.486 & .138 \\
Factor 2 & 2.262 & .133 & & -3.848 & $.000^{*}$ \\
Factor 3 & 2.066 & .151 & & -0.170 & .865 \\
Factor 4 & 0.239 & .625 & & 3.641 & $.000^{*}$ \\
Factor 5 & 0.148 & .700 & & 0.105 & .916 \\
\hline
\end{tabular}

$* p<.01$ 
The public group rated the importance of accountability for the outcomes of collaboration higher than the civil group did. This may be because the outcomes of collaboration are closely related to positive or negative work performance incentives for civil servants. The civil group perceived the clarity of laws and regulations as a more important factor than the outcomes of collaboration. Almost no institutional compensation is given to the chairpersons or members of community councils in relation to the performance of the community centers. Therefore, they can only pursue intangible compensations, such as benefits to their political careers and reputations. The institutional compensations and motives that they can pursue are the clarification of laws and regulations, and it seems that they ultimately pursue the expansion of the authority of community councils through those.

\section{Differences between City and Non-city Groups}

Questionnaire respondents were also divided into a city group (residing in city or $g u$ units) and a non-city group (residing in district or eup or myeon units), and independent sample t-tests were conducted on each. The results indicated that differences between the two groups existed in three out of five factors: accountability of the process of collaboration (factor 1) and in the outcomes of collaboration (factors 4 and 5). These are described in more detail in table 11.

Table 11. Differences between City and Non-city Groups in Perceptions of Factors Affecting the Accountability of Collaborative Governance (independent sample t-test)

\begin{tabular}{cccccc}
\hline \multirow{2}{*}{ Factor } & \multicolumn{2}{c}{ Levene's equal variance test } & & \multicolumn{2}{c}{ t-test for the sameness of means } \\
\cline { 2 - 3 } \cline { 5 - 6 } & $\mathrm{F}$ & $\mathrm{p}$ & & $\mathrm{t}$ & $\mathrm{p}$ \\
\hline Factor 1 & 0.163 & .687 & & -4.177 & $.000^{*}$ \\
Factor 2 & 0.007 & .935 & & -0.141 & .888 \\
Factor 3 & 0.001 & .976 & & 1.384 & .167 \\
Factor 4 & 0.279 & .598 & & 4.252 & $.000^{*}$ \\
Factor 5 & 7.141 & .008 & & 2.184 & $.029^{* *}$ \\
\hline
\end{tabular}

$* p<.01, * * p<.05$

The city group gave more importance to accountability for the outcomes of collaboration (factor 4 and factor 5) than did the non-city group, while the non-city group perceived accountability for the process of collaboration (factor 1) to be more important than did the city group. In general, city groups have larger populations, more diversity and larger budgets than non-city groups. In addition, exchanges between actors depend on formal decision-making processes with high levels of institutional- 
ization rather than on informal contacts and emotional exchanges. The city group, therefore, can be more sensitive to outcomes than the non-city group, and it appears that, for this reason, the city group gave more importance to the accountability of the outcomes of collaboration than the non-city group did. On the other hand, compared to the city group, the non-city group has a smaller regional scope and is more likely to depend on emotional exchange structures based on informal and face-to-face contacts rather than on formal and official exchange methods. Also, their budgets are smaller. From this information, the non-city group can be considered as regarding the accountability of decision-making processes more important than the accountability of direct performances.

This observation suggests that, as in the case of public and civil groups, which must be distinguished to ensure the accountability of community centers, differentiated measures to ensure accountability should be prepared for city groups and non-city groups based on differences in their perceptions. In particular, compensation and motivation systems linked with performance should be established for city groups, and measures to ensure accountability relating to decision-making processes and overall collaboration processes are necessary for non-city groups.

This paper reviewed the factors likely to affect the accountability of the Korean community centers which is an empirical case of collaborative governance system. It suggested five key factors : communication with local residents through transparent and democratic decision-making process, clarity of law and regulation, representativeness and expertise of community council members, performance management, reward and incentive system. The analysis also suggested that it is necessary to conceive different performance management and incentive systems for public and civil groups for a better functioning of collaborative governance arrangements.

\section{REFERENCES}

Alexander, E. R. 1995. How organizations act together: Interorganizational coordination in theory and practice. Australia: Gordon and Breach.

Alter, C., and J. Hage. 1993. Organizations working together. Newbury Park, CA: Sage Publications.

Bae, E.. 2005. Local governance: From conflict to collaboration. Local Administration Studies Review 19(2): 187-215.

Bark, D. 2001. The administrative reform and the accountability of administration. The Study of Korea Public Administration 10(2): 5-21.

Bovens, M. 2007. Analysing and assessing accountability: A conceptual framework. 
European Law Journal 13(4): 447-68.

Choe, H. 2003. Accountability of the local government and the local council. The Study of Local Public Administration 17(3): 131-71.

Choung, W. 1996. On the concepts of responsibility and accountability in a bureaucracy. The Journal of Social Science Studies 15: 215-69.

Cooper, T. L. 1982. The responsible administrator: An approach to ethics for the administrative role, 43-55. New York: Kennikat Press.

Day, P., and Klein, R. 1987. Accountabilities: Five public services. New York: Tavistock Publications.

Dunsire, A. 1996. Tipping the balance: Autopoiesis and governance. Administration \& Society 28(3): 299-334.

Edwards, M., and D. Hulme. 1996. Too close for comfort? The impact of official aid on NGO. World Development 24(6): 961-73.

Erkkila, T. 2007. Governance and accountability: A shift in conceptualization. Public Administration Quarterly 2007:1-38.

Eun, J., et al. 2009. An exploratory research on an accountability index for collaborative governance. Seoul: the Korea Institute of Public Administration (KIPA), Working paper 2009-24.

Gavin, S. 2000. Obstacles to empowerment: Local politics and civil society in metropolitan Manila, the Philippines. Urban Studies 37(12): 2357-75.

Gilbert, C. E. 1969. The framework of administrative responsibility. Journal of Politics 21: 382-83.

Gray, B. 1985. Conditions facilitating interorganizational collaboration. Human Relations 38: 911-36.

1989. Collaborating: Finding common ground for multiparty problems. San Francisco: Jossey-Bass.

Harmon, M. M. 1981. Action theory for public administration. New York: Longman.

Henton, D., J. Melville, T. Amsler, and M. Kopell. 2008. Collaborative governance: A guide for grantmakers. Menlo Park, CA: The William and Flora Hewlett Foundation.

Hong, S. 2004. Raising of collaborative local governance. The Study of Korean Public Administration: 1-19.

Huxham, C. 2000. The challenge of collaborative governance. Public Management 2(3): 337-57.

Jessop, B. 1998. The rise of governance and the risks of failure: The case of economic development. International Social Science Journal 50(155): 29-45.

.2001. Good governance and the urban question: On managing the contradictions of neo-liberalism. Lancaster University. 
2002. The future of the capitalist state. Cambridge: Policy Press.

Jos, P. H., and Tompkins, M. E. 2004. The accountability paradox in an age of reinvention. Administration \& Society 36(3): 255-81.

Kernaghan, K. 1978. Changing concepts of power and responsibility in the Canadian public service. Canadian Public Administration 21(3): 398.

Kim, H. 2008. An application of collaborative governance model in the radioactive waste siting processes in Buan. The Study of Korean Public Administration 20(1): 47-76.

Kim, P. D., and Y. A. Ryoo. 2008. Development strategies for improving residents autonomy focused in local governments. Seoul: Korea Research Institute for Local Administration.

Kim, S., I. No, and M. Lee. 2004. Local revitalization and local NGO: Ensuring accountability in local NGO. The Study of Local Self-Governing: 265-92.

Kim, S., et al. 2002. The comprehensive of governance. Seoul: Taeyoungmunhwasa.

Kim, T., H. Lee, and S. Lee. 2005. The analysis of accountability difference on type of public administration organization culture. The Study of Korea Public Administration: 541-58.

Kooiman, J. 2003. Governing as governance. London: Sage Publications.

Lee, K. 2005. The accountability of public administration. Seoul: Daeyoungmunhwasa.

Lee, S. M. 2005. Residents self-governing center for local community building? Hanyang University Third Sector Institute. Civil Society \& NGO 3(1): 173-207.

Lee, S., and S. Yang. (2007). The study of the accountability of non-governmental organizations and the role of government. In Korea Association of Public Administration, review of summer conference, 79-105.

Lee, Y. Y. 2000. The study on the community center model of local government: The Korean Association For Governance. Korea Governance Review: 149-64.

Mosher, F. 1982. Democracy and the public service. New York: Oxford University Press.

Mulgan, R. 2001. The accountability of community sector agencies: Comparative framework. Third Sector 7(1): 89-105.

Olson, M. 1971. The logic of collective action: Public goods and theory of groups. Cambridge, MA: Harvard University Press.

Ostrom, E. 1990. Governing the commons: The evolution of institutions for collective action. Cambridge: Cambridge University Press.

O’Toole, L. J., Jr. 1997. Treating networks seriously: Practical and research-based agendas in public administration. Public Administration Review 57(1): 45-52.

O'Toole, L. J., Jr., K. J. Meier, and S. Nicholson-Crotty. 2005. Managing upward, downward, and outward: Networks, hierarchical relationships, and performance. 
Public Management Review 7(1): 45-68.

Park, J. 2008. Politics, public administration and governance: Politics and public administration in governance, past, present and future. The Study of Korean Policy: 111-33.

Peters, E. J. 1989. Federal and provincial responsibilities for the James Bay Cree, Naskapi and Init under the James Bay and Northern Quebec Agreement and the Northeastern Quebec Agreement. In D. C. Hawkes (ed.), Aboriginal peoples and government responsibility: Exploring federal and provincial roles. Ottawa: Carleton University Press.

Pierre, J., and B. G. Peters. 2000. Governance, politics and the state. New York: Palgrave Macmillan.

Powell, W. W. 1990. Neither market nor hierarchy: Network forms of organization. In B. M. Straw and L. L. Cummings (ed.), Research in Organizational Behavior (vol. 12, pp. 295-336). Greenwich, CT: JAI Press.

Rhodes, R. A. W. 1997. Understanding governance: Policy networks, governance, reflexivity and accountability. Buckingham: Open University Press.

Ring, P. S., and A. H. Van de Ven. 1994. Development processes of collaborative interorganizational relationships. Academy of Management Review 19(1): 90-118.

Romzek, B. S., and M. J. Dubnick. 2000. Accountability in Shafritz. In M. Jay (ed.), International encyclopedia of public policy and administration (pp. 6-11). Westview Press.

Schedler, A. 1999. Conceptualizing accountability. In L. Diamond (ed.), The selfrestraining state: Power and accountability in new democracies. Boulder, CO: Lynne Rienner.

Schubeler, P. 1996. Participation and partnership in urban infrastructure management (urban management). Washington, DC: World Bank.

Shah, A. 2006. Local governance in developing countries. Washington, DC: World Bank.

Sharkansky, I. 1982. Public administration: Agencies, policies and politics. San Francisco: W. H. Freeman.

Simey, M. 1985. Government by consent: The principles and practice of accountability in local government. London: Bedford Square Press.

Sinclair, A. 1995. The chameleon of accountability: Forms and discourses. Accounting Organization and Society 20(2): 219-37.

Streek, W., and P. C. Schmitter, eds. 1985. Private interest government: Beyond market and state. Beverly Hills, CA: Sage Publications.

Suh, S. T., and B. G. Min. 2005. A study on collaborative governance for regional development. Korean Journal of Regional Studies 30(2): 25-44. 
Tang, S.-Y., and D. A. Mazmanian. 2008. An agenda for the study of collaborative governance. Unpublished manuscript.

Taylor, J. 2007. Company fraud in Victorian Britain: The Royal British Bank Scandal of 1856. The English Historical Review 122(497): 700-724.

Tendler, J. 1997. Good government in the tropics. Baltimore, MD: The Johns Hopkins University Press.

Warren, R. L., A. F. Burgunder, J. W. Newton, and S. M. Rose. 1975. The interaction of community decision organizations: Some conceptual considerations and empirical findings. In A. R. Negandhi (ed.), Inter-organizational theory (pp. 167-81). Kent, OH: Kent State University Press.

Wondolleck, J. M., and S. L. Yaffe. 2000. Making collaborative work. Washington, DC: Island Press.

Yoo, N. K. 2004. The study on the measurement and determinants of the community center's efficiency: The case of the Jinju in Korea. $\mathrm{PhD}$ dissertation, Graduate School of Public Administration, Seoul, Hanyang University. 